\title{
Spatial Dependence Evaluation of Agricultural Technical Efficiency-Based on the Stochastic Frontier and Spatial Econometric Model
}

\author{
Ziqi Yin and Jianzhai $W u *$ (1) \\ Agricultural Information Institute, Chinese Academy of Agricultural Science, No.12 Zhongguancun South Street, \\ Haidian District, Beijing 100081, China; yinziqi666@163.com \\ * Correspondence: wujianzhai@caas.cn
}

Citation: Yin, Z.; Wu, J. Spatial Dependence Evaluation of Agricultural Technical

Efficiency-Based on the Stochastic Frontier and Spatial Econometric

Model. Sustainability 2021, 13, 2708.

https://doi.org/10.3390/su13052708

Academic Editor: Luis Jesús

Belmonte-Ureña

Received: 3 February 2021

Accepted: 26 February 2021

Published: 3 March 2021

Publisher's Note: MDPI stays neutral with regard to jurisdictional claims in published maps and institutional affiliations.

Copyright: (c) 2021 by the authors. Licensee MDPI, Basel, Switzerland. This article is an open access article distributed under the terms and conditions of the Creative Commons Attribution (CC BY) license (https:/ / creativecommons.org/licenses/by/ $4.0 /)$.

\begin{abstract}
In recent years, through the implementation of a series of policies, such as the delimitation of major grain producing areas and the construction of advantageous and characteristic agricultural product areas, the spatial distribution of agriculture in China has changed significantly; however, research on the impact of such changes on the efficiency of agricultural technology is still lacking. Taking 11 cities in Hebei Province as the research object, this study examines the spatial dependence of regional agricultural technical efficiency using the stochastic frontier analysis and spatial econometric analysis. The results show that the improvement in agricultural technical efficiency is evident in all cities in Hebei Province from 2008 to 2017, but there is scope for further improvement. Industrial agglomeration has statistical significance in improving the efficiency of agricultural technology. Further, there is an obvious spatial correlation and difference in agricultural technical efficiency. Optimizing the spatial distribution of agricultural production, promoting the innovation, development, and application of agricultural technology, and promoting the expansion of regional elements can contribute to improving agricultural technical efficiency.
\end{abstract}

Keywords: agricultural technical efficiency; spatial dependence; industrial agglomeration; stochastic frontier; space metrology

\section{Introduction}

While agricultural development has greatly increased food supply over the past half century, it has also consumed nearly $75 \%$ of fresh water resources; farmland or pasture occupies more than $50 \%$ of the global ice-free land area [1-3]. Since the resource requirements of global agriculture are becoming increasingly tense, the intensive and efficient use of agricultural resources has become the focus of future agricultural development [4-6].

Over the years, $7-10 \%$ of China's agricultural gross domestic product (GDP) was used to compensate for the environmental costs of increasing food supply [7]. The development of green and efficient modern agriculture requires that technical efficiency be improved to increase future agricultural supply [8,9]. However, China's current level of agricultural technical efficiency is low $[10,11]$. Given that the concept of green development has been thoroughly implemented, only by improving its efficiency of agricultural production can the increasing demands for food due to population growth and economic development be met [12]. In this context, it is of great practical significance to explore the influencing factors and mechanisms of agricultural technical efficiency in the new period.

Agricultural technical efficiency is affected by many factors. First, at the regional macro level, Sabasi and Shumway [13] revealed that technological progress can significantly promote agricultural technical efficiency. Ghoshal and Goswami [14] and Shuaibu and Nchake [15] showed that economic development, education level, and scale level will have an impact on agricultural technical efficiency. Shanmugam and Venkataramani [16] pointed that agricultural technical efficiency across districts depends greatly on public 
health and environmental factors, such as agro-climatic zones. Sunge and Ngepah [17] and Quiroga et al. [18] believed that agricultural technical efficiency can also be affected by institutional policies. Second, on the individual level of farmers, Yonas et al. [19] and Wanglin Ma et al. [20] suggested that management measures influences farmers' technical efficiency. Naveed et al. [21] and Ojiya et al. [22] showed that the infrastructure and return rate of production input have a significant impact on farmers' technical efficiency. Chen et al. [23]. revealed that technical efficiency is also related to the age of the household head and the village migration ratio. Spatial dependence reflects the spatial interaction of economic behaviors caused by the flow of various variables, such as labor, capital, and other economic factors among regions [24]. Scholars have pointed out that economic development, market price, stock risk, energy development, and other aspects of social and economic development show spatial dependence [25-27]. In recent years, many studies have introduced the spatial characteristics of technical efficiency into the literature, and its positive spatial externality has been found both at regional and enterprise levels [28-30].

In recent years, China has continued to promote the construction of major grainproducing and special-quality areas. The pattern of agricultural production has significantly changed, and more industrial clusters have emerged [31-34]. Most of the existing studies in the literature only analyzed the evolution and influencing factors of China's agricultural technical efficiency based on time, or compared the horizontal regional technical efficiency based on cross-sectional data. China's agricultural technical efficiency has rarely been examined from a spatial perspective. Taking Hebei Province as an example, this study applies a spatial econometric analysis to measure spatial influencing factors on the basis of using the stochastic frontier model to evaluate agricultural technical efficiency. Hebei Province is a major agricultural province in China, which is the main production area of wheat, corn, cotton, vegetables, fruits, and other major food crops. It is the core of Beijing, Tianjin, and Hebei metropolitan area, being the main source of grain and food supply in the region, and makes an important contribution to the national food security. The study of agricultural efficiency in Hebei province is not only of great significance to the provincial economic development, but also has practical significance for the metropolitan area and even the whole country. Compared with previous studies, we not only consider panel data characteristics, but also the spatial correlation of agricultural production, which can provide a new perspective for the analysis of factors affecting agricultural technical efficiency.

\section{Materials and Methods}

\subsection{Overview of the Study Area}

Hebei Province is located in North China, bounded between $36^{\circ} 05-42^{\circ} 40 \mathrm{~N}$ and $113^{\circ} 27-119^{\circ} 50 \mathrm{E}$, with a total area of $188,800 \mathrm{~km}^{2}$. It surrounds Beijing and Tianjin, with the Bohai Sea in the east, Taihang Mountain in the west, and Yanshan Mountain in the north. The terrain is high in the northwest and low in the southeast, and inclines from northwest to southeast. It has a temperate continental monsoon climate, with an average annual precipitation of $484.5 \mathrm{~mm}$. It has four distinct seasons with a frost-free period of $81-204$ days, an average temperature below $3{ }^{\circ} \mathrm{C}$ in January, and between $18{ }^{\circ} \mathrm{C}$ and $27^{\circ} \mathrm{C}$ in July.

Hebei Province governs 11 prefecture-level cities, including Shijiazhuang, Tangshan, Qinhuangdao, Handan, Xingtai, Baoding, Zhangjiakou, Chengde, Cangzhou, Langfang, and Hengshui. By the end of 2017, the added value of its primary industryagriculture-was 313 billion yuan, up 3.9\% year on year, and its residential population was at 75.1952 million.

\subsection{Methods}

\subsubsection{Stochastic Frontier Model—Measurement of Agricultural Technical Efficiency}

An Input-Output Analysis is often used to study technical efficiency, which is a set of analytical methods proposed by economist Wassily Leontief to analyze the flow of goods and funds among various sectors of the economic system [35]. The total output 
value of agriculture, forestry, animal husbandry, and fishery is taken as the output (y) in the agricultural production function according to the research needs of this study. The input variables are crop planting area (x1), rural labor force of agriculture, forestry, animal husbandry, and fishery (x2), total power of agricultural machinery ( $x 3)$, and the pure application amount of agricultural fertilizer $(x 4)$. Among them, the sown area of crops represents land input; the rural labor force of agriculture, forestry, animal husbandry, and fishery represent labor input; the total power of agricultural machinery represents the agricultural capital stock; and the pure application amount of agricultural fertilizer represents the intermediate input.

Production frontier analysis is commonly used to measure technical efficiency. It can be divided into non-parametric and parametric methods according to whether the specific form of the production function is known. The former is represented by data envelopment analysis (DEA), while the latter by stochastic frontier analysis (SFA).

DEA is a linear programming method, which has been widely used in efficiency research of different industries and departments since it was proposed by A. Charnes and W. W. Cooper in 1978 [36]. For example, Moutinho et al. [37], Namazi and Mohammadi [38], and Laurinavicheius and Rimkuvienè [39] applied this method to the study of ecological efficiency, resource efficiency, and agricultural production efficiency, respectively.

SFA is a parametric frontier method, which was founded by Battese G.E. and Coelli T.J. in 1992 [40]. Compared with the non-parametric method, the stochastic frontier model is easier to explain and can estimate the reliability of the results [41]. What is more, DEA does not estimate the impact of random disturbance on production activities. There is a large noise in agricultural production [42], which causes the measurement of agricultural technical efficiency in DEA to have inevitable estimation bias. SFA takes into account the impact of such random factors on output. Therefore, it is favored by an increasing number of scholars and has been applied to the evaluation of agricultural technical efficiency in many countries and regions around the world [43-47]

The panel stochastic frontier model was used to investigate technical efficiency. Its basic form is as follows:

$$
Y_{i t}=f\left(X_{i t}, \beta\right) \exp \left(V_{i t}-U_{i t}\right)
$$

In Equation (1), $Y_{i t}$ is the output of the ith region at time $\mathrm{t} ; f\left(X_{i t}, \beta\right)$ is the production function; $X_{i t}$ is the production input; and $\beta$ is the parameter to be estimated. $V_{i t}$ is the random error of the system, which obeys the normal distribution, that is, $V_{i t} \sim N\left(0, \sigma^{2}\right)$. $U_{i t}$ is the error caused by technical inefficiency, which obeys a truncated normal distribution, that is, $U_{i t} \sim N^{+}\left(m, \sigma^{2}\right)$. We suppose that $V_{i t}$ and $U_{i t}$ are independent of each other.

This study assumes that the agricultural production function is in the form of a transcendental logarithm. Combined with the selected variables, Equation (1) can be transformed into a specific form of agricultural production function in Hebei city, as shown in Equation (2):

$$
\begin{aligned}
\ln Y_{i t}= & \beta_{0}+\beta_{1} \ln x_{1}+\beta_{2} \ln x_{2}+\beta_{3} \ln x_{3}+\beta_{4} \ln x_{4}+\beta_{5}\left(\ln x_{1}\right)^{2}+ \\
& \beta_{6}\left(\ln x_{2}\right)^{2}+\beta_{7}\left(\ln x_{3}\right)^{2}+\beta_{8}\left(\ln x_{4}\right)^{2}+\beta_{9} \ln x_{1} \ln x_{2}+ \\
& \beta_{10} \ln x_{1} \ln x_{3}+\beta_{11} \ln x_{1} \ln x_{4}+\beta_{12} \ln x_{2} \ln x_{3}+ \\
& \beta_{13} \ln x_{2} \ln x_{4} \beta_{14} \ln x_{3} \ln x_{4}+\left(V_{i t}-U_{i t}\right)(i=1,2, \ldots, 11 ; t=1,2, \ldots, 10)
\end{aligned}
$$

Equation (2) is in the form of a logarithm on both sides of the stochastic frontier production function.

\subsubsection{Spatial Econometric Model—Analysis of Agricultural Technical Efficiency Factors}

The value of agricultural technical efficiency (expressed by ate) in the function measured by the stochastic frontier model is taken as the explained variable. The core variable of this study is the industrial agglomeration index (agg), also known as the regional specialization index, which is measured by location entropy. It is an effective index used to measure the degree of industrial agglomeration [48]. 


$$
I A I_{i j}=\frac{e_{i j} / \sum_{1}^{11} e_{i j}}{\sum_{1}^{3} e_{i j} / \sum_{1}^{11} \sum_{1}^{3} e_{i j}}
$$

where $I A I_{i j}$ is the location entropy of industry $j$ in city $i$, and $e_{i j}$ is the output value of industry $j$ in city $i . i=1.2 .3 \ldots 11, j=1,2,3$, representing primary, secondary, and tertiary industries. This study only calculates the location entropy of the primary industry in each city. The higher the location entropy, the higher the degree of agglomeration.

The control variables include the following:

(1) Technical factors: Measured by the logarithm of the number of rural science and technology practitioners (lnatp), representing the local agricultural science and technology extension service level.

(2) Economic structure: Since the agglomeration factor is the agglomeration of the primary industry, the proportion of the tertiary industry (pti) was calculated to measure the economic structure, that is, the proportion of the output value of the tertiary industry in the GDP.

(3) Infrastructure: Measured in the form of the logarithm of the effective irrigation area (lneia), reflecting the water conservancy infrastructure conditions of local agricultural production.

(4) Income level: Measured in the logarithmic form of per capita GDP (lnpgdp), reflecting the economic development level or local income level.

(5) Scale level: Measured by per capita sown area (psa), that is, the ratio of the total sown area to the labor force of agriculture, forestry, animal husbandry, and fishery, reflecting the land resources owned by the labor force.

(6) Industrial structure: Measured by the proportion of grain sown area (pga), that is, the ratio of grain sown area to total sown area, representing the proportion of traditional crop planting in agricultural production activities.

(7) Natural factors: In terms of temperature (tem), the influence of annual average temperature change on agricultural technical efficiency was investigated.

(8) Regional factor: The spatial weight matrix $\mathrm{W}$ was introduced. We selected the inverse distance matrix as the spatial weight matrix and defined it as the reciprocal matrix of the distance of the cities' center.

The model used in this research was mainly based on the improved form of the spatial econometric model proposed by Lee [49] and Elhorst [50]. In the empirical study, we used the external command in Stata to build the model.

Three types of models were constructed: The spatial autoregressive model (SAR) (Equation (3)), spatial error model (SEM) (Equation (4)), and spatial Durbin model (SDM) (Equation (5)).

$$
\begin{gathered}
E F_{i, t}=\alpha+\beta \text { Control }_{i t}+\rho \sum_{j}^{11} w_{i j} E F_{j . t}+u_{i}+\varepsilon_{i t} \\
E F_{i, t}=\alpha+\beta \text { Control }_{i t}+u_{i}+\varepsilon_{i t}+\lambda \sum_{j}^{11} w_{i j} \varepsilon_{j t} \\
E F_{i, t}=\alpha+\beta \text { Control }_{i t}+\rho \sum_{j}^{11} w_{i j} E F_{j . t}+\delta \sum_{j}^{11} w_{i j} \operatorname{Control}_{j t}+u_{i}+\varepsilon_{i t} \\
(i=1,2, \ldots, 11 ; t=1,2, \ldots, 10)
\end{gathered}
$$

where $i$ and $j$ represent the region, and $t$ is the time. $E F_{i, t}$ is the agricultural technical efficiency of city $i$ at time $t$; Control $_{i t}$ is a matrix composed of control variables, including the industrial agglomeration index (agg), logarithm of the number of rural science and technology practitioners (lnatp), proportion of the tertiary industry (pti), logarithm of effective irrigation area (lneia), logarithm of per capita GDP (lnpgdp), per capita sown area (psa), proportion of grain-sown area (pga), and annual average temperature (tem). $u_{i}$ is 
the intercept term of the spatial fixed effect; $w_{i j}$ is the element of row $i$ and column $j$ of the spatial weight matrix. $w_{i j}$ plays a different role in Equations (3)-(5). In Equation (3), it interacts with the spatial lag dependent variable $E F_{j . t}$. In Equation (4), $w_{i j}$ interacts with the spatially correlated random error term $\varepsilon_{j t}$. In Equation (5), $w_{i j}$ interacts with both the spatial lag dependent variable $E F_{j . t}$ and independent variables. Table 1 shows the variable description of the spatial analysis in this paper.

Table 1. Descriptive statistics of key variables.

\begin{tabular}{cccccc}
\hline Variable & Obs & Mean & SD & Min & Max \\
\hline ate & 110 & 0.522 & 0.138 & 0.259 & 0.8 \\
agg & 110 & 1.103 & 0.259 & 0.673 & 1.743 \\
lnatp & 110 & 6.964 & 0.876 & 5.489 & 8.656 \\
pti & 110 & 0.381 & 0.062 & 0.248 & 0.529 \\
lneia & 110 & 12.77 & 0.566 & 11.414 & 13.411 \\
lnpgdp & 110 & 10.394 & 0.409 & 9.557 & 11.326 \\
psa & 110 & 0.158 & 0.038 & 0.096 & 0.252 \\
pga & 110 & 0.711 & 0.063 & 0.589 & 0.917 \\
tem & 110 & 12.349 & 2.19 & 7.1 & 14.8 \\
\hline
\end{tabular}

This paper studies the spatial econometric model according to the research paradigm of Lesage and Pace [51]. First, the overall and local Moran index (I value) was used to test whether there is an overall spatial correlation and local spatial correlation in agricultural technical efficiency. Then, we estimated the three models in Equations (3)-(5), and used the Hausman test to determine that we should choose the spatial panel fixed effect model for our data. We then tested the following assumptions when estimating the spatial econometric model:

Hypothesis 1 (H1). $H_{0}: \theta=\delta_{1}=\delta_{2}=\ldots=\delta_{6}=0$

Hypothesis 2 (H2). $H_{0}:(\theta=-\rho \gamma)\left(\delta_{1}=-\rho \beta_{1}\right)\left(\delta_{2}=-\rho \beta_{2}\right) \ldots\left(\delta_{6}=-\rho \beta_{6}\right)$

For Hypotheses 1 and 2, the Wald test was used to check whether the model parameters are linear. If hypothesis 1 is rejected, SDM is more suitable than SAR; If hypothesis 2 is rejected, SDM is more suitable than SEM. Finally, we replaced the SDM with the spatial auto-correlation model (SAC) to re-estimate the data to test the robustness.

\subsection{Data Sources}

The data used in this study were mainly obtained from the Hebei Rural Statistical Yearbook, Hebei Economic Yearbook, statistical yearbooks of various cities, statistical bulletin of national economic and social development, China Urban Statistical Yearbook, and China Meteorological Statistical Yearbook. To eliminate the impact of price fluctuations, the total output value of agriculture, forestry, animal husbandry, and fishery were converted into comparable prices based on data from 2008.

\section{Results}

\subsection{Estimation Results of the Stochastic Frontier Production Function}

The maximum likelihood function estimation results show that the agricultural production function model has a good fitting effect (Table 2). The significant one-sided likelihood ratio (LR) indicates that the error term has an obvious compound structure. $\sigma^{2}$ and $\gamma$ are highly significant, which indicates that there is obvious efficiency loss in the agricultural technical efficiency of Hebei Province. 
Table 2. Production function estimation results of stochastic frontier model.

\begin{tabular}{cccc}
\hline Parameter & Coefficient & S.D. & T Value \\
\hline$\sigma^{2}$ & 0.0363 & 0.0041 & 8.7670 \\
$\gamma$ & 0.9492 & 0.0107 & 88.4930 \\
\multicolumn{3}{c}{ One sided test value of maximum likelihood function $=221.1584$} \\
\hline
\end{tabular}

The results show that the 11 regions in Hebei Province have a low level of agricultural efficiency (Table 3). During the study period, the agricultural efficiency gradually improved, with the average value increasing from 0.4462 in 2008 to 0.5950 in 2017 . At the same time, the efficiency of agricultural technology shows obvious regional differences. Among the 11 regions, Xingtai had an average efficiency level of 0.3427 ; its lowest level was recorded at 0.2590 in 2008, but this increased to 0.4273 in 2017. Qinhuangdao had the highest level of efficiency, averaging 0.7533, which increased to 0.8001 in 2017.

Table 3. Agricultural technical efficiency and average efficiency of cities in Hebei Province in 2008 and 2017.

\begin{tabular}{ccc}
\hline City | Year & $\mathbf{2 0 0 8}$ & $\mathbf{2 0 1 7}$ \\
\hline Shijiazhuang & 0.5121 & 0.6563 \\
Handan & 0.3311 & 0.4987 \\
Xingtai & 0.2590 & 0.4273 \\
Baoding & 0.3004 & 0.4692 \\
Zhangjiakou & 0.4532 & 0.6077 \\
Chengde & 0.3762 & 0.5405 \\
Tangshan & 0.5259 & 0.6673 \\
Qinhuangdao & 0.7017 & 0.8001 \\
Cangzhou & 0.4890 & 0.6375 \\
Hengshui & 0.3104 & 0.4789 \\
Langfang & 0.6489 & 0.7617 \\
\hline Average efficiency & 0.4462 & 0.5950 \\
\hline
\end{tabular}

\subsection{Estimation Results of the Spatial Econometric Model}

\subsubsection{Spatial Auto-Correlation Test of Agricultural Technical Efficiency}

First, this paper uses the global Moran index (I value) to test whether agricultural technical efficiency has spatial correlation at the prefecture level. The Moran test was used as follows [52]:

$$
\mathrm{I}=\frac{n \sum_{i=1}^{n} \sum_{j=1}^{n} w_{i j}\left(A E F_{i}-\overline{A E F}\right)\left(A E F_{j}-\overline{A E F}\right)}{\sum_{i=1}^{n}\left(A E F_{i}-\overline{A E F}\right)^{2} \sum_{i=1}^{n} \sum_{j=1}^{n} w_{i j}}
$$

where $i$ and $j$ represent cities, $w_{i j}$ is the element of row $i$ and column $j$ in the spatial weight matrix, $A E F_{i}$ is the agricultural technical efficiency of city $i$, and $\overline{A E F}$ is the overall average technical efficiency among cities.

In Table 4 , the $p$-value indicated a significance level of less than 0.05 , that is, the Moran index I is significant at the $5 \%$ level from 2008 to 2017. This also indicates that agricultural technical efficiency has spatial autocorrelation at the prefecture level. As time progressed, the Moran index increased year by year, and the spatial agglomeration of agricultural technical efficiency became increasingly evident.

Furthermore, to investigate local spatial correlation, this study used the local Moran index and Moran scatter plot (MSP) to test agricultural technical efficiency at the prefecture level. The results show that Baoding, Hengshui, Xingtai, and Handan have low-low agglomeration, while high-high agglomeration occurs in Langfang, Tangshan, and Qinhuangdao. 
Table 4. Global Moran index and $p$ value from 2008 to 2017.

\begin{tabular}{ccc}
\hline Year & Moran Index & $p$-Value \\
\hline 2008 & 0.041 & 0.043 \\
2009 & 0.042 & 0.043 \\
2010 & 0.042 & 0.043 \\
2011 & 0.043 & 0.042 \\
2012 & 0.043 & 0.042 \\
2013 & 0.044 & 0.042 \\
2014 & 0.044 & 0.041 \\
2015 & 0.044 & 0.041 \\
2016 & 0.045 & 0.041 \\
2017 & 0.045 & 0.041 \\
\hline
\end{tabular}

\subsubsection{Influencing Factors of Agricultural Technical Efficiency}

Three models of spatial metrology were selected for estimation based on the analysis above, as shown in Table 5. We estimated the spatial panel Durbin model (SDM), spatial panel autoregressive model (SAR), and spatial panel error model (SEM) from the perspective of the FE and RE. The results of the Wald test reject the original hypothesis, that is, SAR and SEM models cannot accurately describe the spatial relationship of our data; therefore, the SDM model should be used for analysis. Compared with the SAR and SEM models, SDM considers the common influence of the spatial lag explanatory variable on the explained variable, and has the general form of the spatial lag model and spatial error model. As the only model that can obtain unbiased coefficient estimation, SDM decomposes the total impact into direct and indirect impacts. It can more comprehensively measure the spatial spillover effect of each individual observation from different angles based on panel data [53].

Table 5. Estimation results of spatial Durbin model, spatial autoregressive model, and spatial error model.

\begin{tabular}{|c|c|c|c|c|c|c|}
\hline Var I Model & SDM FE & SDM RE & SAR FE & SAR RE & SEM FE & SEM RE \\
\hline agg & $\begin{array}{c}0.0336^{* * *} \\
(4.11)\end{array}$ & $\begin{array}{c}0.0352^{* * *} \\
(4.04)\end{array}$ & $\begin{array}{c}0.0341^{* * * *} \\
(3.65)\end{array}$ & $\begin{array}{c}0.0357^{* *} \\
(3.59)\end{array}$ & $\begin{array}{c}0.0472^{* * *} \\
(3.99)\end{array}$ & $\begin{array}{c}0.0471^{* * *} \\
(3.83)\end{array}$ \\
\hline lnatp & $\begin{array}{c}0.0111^{* *} \\
(2.29)\end{array}$ & $\begin{array}{c}0.0105^{* *} \\
(2.03)\end{array}$ & $\begin{array}{c}0.0074 \\
(1.39)\end{array}$ & $\begin{array}{c}0.0057 \\
(1.01)\end{array}$ & $\begin{array}{c}0.0046 \\
(0.69)\end{array}$ & $\begin{array}{c}0.0028 \\
(0.40)\end{array}$ \\
\hline pti & $\begin{array}{c}0.0733 \text { * } \\
(1.76)\end{array}$ & $\begin{array}{c}0.0765 \text { * } \\
(1.74)\end{array}$ & $\begin{array}{c}0.0957^{* *} \\
(2.50)\end{array}$ & $\begin{array}{c}0.1145^{* * *} \\
(2.77)\end{array}$ & $\begin{array}{c}0.4311^{* * *} \\
(14.70)\end{array}$ & $\begin{array}{c}0.4403^{* * *} \\
(14.85)\end{array}$ \\
\hline lneia & $\begin{array}{c}0.0048 \\
(0.40)\end{array}$ & $\begin{array}{c}0.0073 \\
(0.59)\end{array}$ & $\begin{array}{c}0.0160 \\
(1.16)\end{array}$ & $\begin{array}{r}0.0107 \\
(0.73)\end{array}$ & $\begin{array}{c}0.0122 \\
(0.85)\end{array}$ & $\begin{array}{c}0.0042 \\
(0.29)\end{array}$ \\
\hline $\operatorname{lnpgdp}$ & $\begin{array}{c}0.0599 * * * \\
(4.26)\end{array}$ & $\begin{array}{c}0.0686^{* * *} \\
(4.62)\end{array}$ & $\begin{array}{c}0.0599 * * * \\
(5.03)\end{array}$ & $\begin{array}{c}0.0662^{* * *} \\
(5.11)\end{array}$ & $\begin{array}{c}0.1488^{* * *} \\
(27.43)\end{array}$ & $\begin{array}{c}0.1480^{* * * *} \\
(26.70)\end{array}$ \\
\hline psa & $\begin{array}{c}0.2412 \text { ** } \\
(2.30)\end{array}$ & $\begin{array}{c}0.2101 \text { * } \\
(1.87)\end{array}$ & $\begin{array}{c}0.1690 \\
(1.38)\end{array}$ & $\begin{array}{c}0.1539 \\
(1.19)\end{array}$ & $\begin{array}{c}0.0664 \\
(0.43)\end{array}$ & $\begin{array}{c}0.0431 \\
(0.27)\end{array}$ \\
\hline pga & $\begin{array}{l}-0.0263 \\
(-1.12)\end{array}$ & $\begin{array}{l}-0.0275 \\
(-1.10)\end{array}$ & $\begin{array}{l}-0.0002 \\
(-0.01)\end{array}$ & $\begin{array}{l}-0.0013 \\
(-0.04)\end{array}$ & $\begin{array}{l}-0.0139 \\
(-0.41)\end{array}$ & $\begin{array}{l}-0.0197 \\
(-0.56)\end{array}$ \\
\hline tem & $\begin{array}{c}0.0009 \\
(1.59)\end{array}$ & $\begin{array}{c}0.0006 \\
(1.11)\end{array}$ & $\begin{array}{c}0.0008 \\
(1.21)\end{array}$ & $\begin{array}{c}0.0007 \\
(1.08)\end{array}$ & $\begin{array}{c}0.0004 \\
(0.46)\end{array}$ & $\begin{array}{c}0.0003 \\
(0.31)\end{array}$ \\
\hline Cons & & $\begin{array}{c}-0.4484 \\
(-1.57)\end{array}$ & & $\begin{array}{c}-0.7556^{* * *} \\
(-3.13)\end{array}$ & & $\begin{array}{c}-1.3050 \text { **** } \\
(-6.18)\end{array}$ \\
\hline $\mathrm{N}$ & 110 & 110 & 110 & 110 & 110 & 110 \\
\hline rsq & 0.006 & 0.154 & 0.040 & 0.011 & 0.614 & 0.669 \\
\hline R2_w & 0.9798 & 0.9788 & 0.9559 & 0.9577 & 0.9327 & 0.9317 \\
\hline
\end{tabular}

Note: ${ }^{* * *}$ indicates significant correlation when the confidence level is $0.01,{ }^{* *}$ means significant correlation when the confidence level is $0.05, *$ means significant correlation when the confidence level is 0.1 , and the $t$-test values of regression variables are in brackets.

To test the fixed effect (FE) and random effect (RE) of SDM, the Hausman test was used. Because the p-value of SDM significantly rejects the original hypothesis at the $1 \%$ level (assuming that RE is more effective than FE), we chose to explain the SDM FE model. 
Furthermore, according to the method proposed by Lesage and Space [51], we report the marginal impact of each explanatory variable on agricultural technical efficiency, as shown in Table 6.

Table 6. Average marginal impact.

\begin{tabular}{cccc}
\hline Var & Direct Impact & Indirect Impact & Total Impact \\
\hline \multirow{2}{*}{ agg } & $0.0312^{* * *}$ & $0.1020^{* * *}$ & $0.1332^{* * *}$ \\
& $(3.77)$ & $(3.11)$ & $(3.76)$ \\
lnatp & $0.0094^{* *}$ & $0.0605^{* * *}$ & $0.0699^{* * *}$ \\
& $(1.97)$ & $(2.64)$ & $(2.80)$ \\
pti & $0.0623^{*}$ & $0.5547^{* * *}$ & $0.6169^{* * *}$ \\
& $(1.81)$ & $(8.23)$ & $(10.51)$ \\
lneia & 0.0058 & $-0.0449^{*}$ & -0.0392 \\
& $(0.47)$ & $(-2.31)$ & $(-1.58)$ \\
lnpgdp & $0.0589^{* * *}$ & $0.0448^{* * *}$ & $0.1037^{* * *}$ \\
& $(4.37)$ & $(3.10)$ & $(8.20)$ \\
psa & $0.2252^{* *}$ & $0.9610^{* *}$ & $1.1862^{* *}$ \\
& $(2.13)$ & $(1.79)$ & $(2.08)$ \\
pga & -0.0187 & $-0.2533^{* * *}$ & $-0.2720^{* * *}$ \\
& $(-0.73)$ & $(-3.56)$ & $(-3.63)$ \\
tem & $0.0008^{*}$ & 0.0011 & 0.0020 \\
& $(1.58)$ & $(0.55)$ & $(0.87)$ \\
\hline
\end{tabular}

Note: ${ }^{* * *}$ indicates significant correlation when the confidence level is $0.01,{ }^{* *}$ indicates significant correlation when the confidence level is $0.05, *$ means significant correlation when the confidence level is 0.1 , and the $t$-test values of regression variables are in brackets.

The direct impact coefficient of industrial agglomeration (agg) is 0.0312 , which is significant at the $1 \%$ level. This means that when the level of industrial agglomeration increases by $1 \%$, the agricultural technical efficiency of the region increases by $0.0312 \%$. Industrial agglomeration has a positive direct effect on regional agricultural technical efficiency through the spatial correlation of regional economic development. Meanwhile, it produces a positive indirect effect-spatial spillover effect. This spillover effect affects other regions, forming a cumulative effect. The indirect impact coefficient is 0.1020 , which is significant at the $1 \%$ level; every $1 \%$ increase in the level of local industrial agglomeration can raise the agricultural technical efficiency of neighboring areas by $0.1020 \%$. The spatial effect of industrial agglomeration on agricultural technical efficiency is such a dynamic adjustment. When the positive direct and spatial spillover effects are combined, the cumulative long-term effect is positive. When the level of industrial agglomeration increases by $1 \%$, the overall agricultural technical efficiency increases by $0.1332 \%$. This process can be seen as the path of industrial agglomeration to promote the improvement of agricultural technical efficiency.

The study also showed that the number of rural science and technology practitioners (lnatp), proportion of the tertiary industry (pti), and per capita GDP (lnpgdp) have a positive impact on agricultural technical efficiency at the $1 \%$ significance level, and the effect of per capita sown area (psa) was significant at $5 \%$. The proportion of grain sown area (pga) has a negative impact on agricultural technical efficiency, which is significant at the $1 \%$ level. The effects of the effective irrigation area (lneia) and temperature (tem) were not statistically significant.

\subsubsection{Robustness Analysis}

The SAC model was further used for re-estimation, and the results were compared with those of SDM. After changing the method, the main effect coefficient of industrial agglomeration was still positive, which was significant at the $1 \%$ level. The main effect coefficient of key variables, such as the number of rural science and technology practitioners, proportion of the tertiary industry, and per capita GDP, was still positive, proving the robustness of the previous estimation. 


\section{Discussion}

The results show that there is obvious spatial heterogeneity of agricultural technical efficiency in Hebei Province. The city with the lowest efficiency level is Xingtai, and the highest is Qinhuangdao. The possible reason is that there are differences in natural resource endowment, economic base, technology level, and industrial structure among cities in Hebei. Qinhuangdao is located along the coast of the Bohai Sea with high levels of economic and social development. The city's developed sea transportation method is convenient for the transportation of agricultural products. It also has more economic exchanges, which stimulate consumption and drive local agricultural production activities, modernizing agricultural production. Qinhuangdao also pays attention to the popularization and application of technology, so its agricultural technical efficiency is higher. Xingtai is located in the inland area, which mainly relies on traditional cultivation because the resource and transportation conditions of its agricultural development are relatively limited. Overall, the agricultural technical efficiency of each region has increased year by year and is developing rapidly.

The results also show that there is spatial spillover effect of agricultural technical efficiency in Hebei Province, and the spatial agglomeration of efficiency becomes more and more significant as time goes on. The improvement in industrial agglomeration level has a significant role in promoting the agricultural technical efficiency of local and adjacent areas, which shows positive direct impact and indirect impact respectively. The possible mechanisms are as follows. In regard to the direct impact for the region, on the one hand, industrial agglomeration suggests that there are more production and operational entities in local regions. Fierce market competition pushes them to actively learn advanced technology and experience, upgrade, and transform production equipment to reduce costs and increase competitiveness, thus driving technological progress and enhancing labor quality. On the other hand, areas with high levels of industrial agglomeration tend to pay more attention to the layout of industrial development. A reasonable production pattern can make better use of agricultural technology. In regard to the indirect impact for neighboring areas, the regional economy is an open system, and the interactive mechanism of spatial correlation promotes the innovating, leading, driving, and demonstrating functions of industrial agglomeration regions. The diffusion of innovation activities and innovative achievements can continuously strengthen regional economic ties. Additionally, the spillover of knowledge and technology is conducive to their technological progress and innovation, thus improving overall agricultural technical efficiency, which can be explained by agricultural technology spillover theory [54]. The coordinated development, cooperation, and exchange between regions can tap the development potential of backward areas, give full play to the advantages of backwardness, and gradually improve overall agricultural technical efficiency.

In recent years, China has continuously optimized the layout of agricultural development and industrial structure, accelerated the construction of agricultural functional areas, and launched development strategies such as the construction of major grain producing areas and advantageous agricultural product producing areas. This is bound to further promote the agglomeration of agricultural industry in space. As this paper studied, industrial agglomeration has a significant pulling effect on agricultural technical efficiency, as is consistent with that of scholars on the agglomeration of technical efficiency [55,56]. However, at the same time, there is spatial competition in the development of regional agricultural industry. The improvement of industrial agglomeration level may lead to the flow of technology, labor, capital, and other factors to the local, and increase the difference of agricultural technical efficiency among regions [57-59]. Therefore, local governments should speed up the formation of a scientific and reasonable layout of agricultural industry development and establish a healthy market operation order. This can maximize the advantages of industrial agglomeration, which is of great significance to improve the agricultural technical efficiency. 


\section{Conclusions}

This paper first estimates the agricultural technical efficiency of cities in Hebei Province through the stochastic frontier production function. While the agricultural technical efficiency of Hebei cities significantly improved from 2008 to 2017, there is still much room for development; there is obvious correlation and heterogeneity in space, showing the distribution characteristics of high-high agglomeration and low-low agglomeration. Through a positive spatial spillover effect, industrial agglomeration has a pulling impact on the agricultural technical efficiency. Technical level, economic structure, income level, and scale level have a positive impact on agricultural technical efficiency, while agricultural industrial structure has a negative impact.

Based on these conclusions, we suggest implementing the following policies to further improve agricultural technology efficiency. First, we recommend promoting the agglomeration of regional technology, capital, talent, and other elements to optimize the spatial distribution and industrial structure of agricultural production, with a strong focus on the construction of agricultural functional areas and major grain producing areas. Second, we recommend strengthening financial, technological, and educational support for agricultural departments to promote the innovation, development, and application of agricultural technology, which can directly contribute to agricultural technical efficiency. Third, we recommend developing and expanding regional technology and capital, training more agricultural science and technology talents, to play a positive spatial spillover effect through industrial agglomeration.

Based on a spatial econometric model, our study contributes to enriching theoretical and practical knowledge about the impact of industrial agglomeration on agricultural technical efficiency, and helping improve managerial practices by highlighting the importance of the spatial distribution and industrial structure of agricultural production in our policy suggestions. There are more in-depth research projects for the future. First, our results show that Hebei's agricultural technical efficiency has obvious spatial correlation and heterogeneity. Agglomeration can promote the agricultural technical efficiency at the municipal level, but the effects at the county level remain unknown. Hence, research using the data on a smaller scale is necessary in the future with the improvement of statistical data. Second, we mainly use the spatial parametric models in this study to estimate the linear spatial effect. The spatial nonparametric models can also be adopted to analyze the nonlinear relationship between agricultural technical efficiency and agricultural industrial agglomeration in the future.

Author Contributions: Conceptualization, Z.Y.; methodology, Z.Y. and J.W.; software, Z.Y.; validation, Z.Y. and J.W.; formal analysis, Z.Y. and J.W.; investigation, Z.Y.; resources, J.W.; data curation, Z.Y. and J.W.; writing-original draft preparation, Z.Y.; writing-review and editing, Z.Y. and J.W.; visualization, J.W.; supervision, J.W.; project administration, J.W.; funding acquisition, J.W. All authors have read and agreed to the published version of the manuscript.

Funding: This work was funded by Central Public-interest Scientific Institution Basal Research Fund, JBYW-AII-2021-08; JBYW-AII-2020-52; Youth Program of National Natural Science Foundation of China, 71703159; and Chinese Academy of Agricultural Science Jointly Tackle Key Scientific Research Tasks, CAAS-ZDRW202012.

Institutional Review Board Statement: This research is not human or animal research and no sensitive data is obtained or used. Therefore, it is not necessary to specify Institutional Review Board Statement.

Informed Consent Statement: Informed consent was obtained from all respondents interviewed in the study.

Data Availability Statement: The qualitative data on which narratives are based is contained in the article. Further information is available from authors upon reasonable request.

Acknowledgments: The authors would like to thank Chinese Academy of Agricultural Science for providing support to conduct this research. Furthermore, we would like to thank our colleagues 
at Agricultural Information Institute for their support in data collection, field visits, and valuable thoughts for the preparation of this manuscript.

Conflicts of Interest: The authors declare no conflict of interest.

\section{References}

1. Tilman, D.; Clark, M. Global diets link environmental sustainability and human health. Nature 2014, 515, 518-522. [CrossRef] [PubMed]

2. Koondhar, M.A.; Li, H.; Wang, H.; Bold, S.; Kong, R. Looking back over the past two decades on the nexus between air pollution, energy consumption, and agricultural productivity in China: A qualitative analysis based on the ARDL bounds testing model. Environ. Sci. Pollut. Res. Int. 2020, 27, 13575-13589. [CrossRef] [PubMed]

3. Jiang, Y.; Chen, S.; Hu, B.; Zhou, Y.; Shi, Z. A comprehensive framework for assessing the impact of potential agricultural pollution on grain security and human health in economically developed areas. Environ. Pollut. 2020, 263, 114653. [CrossRef]

4. Hadjikakou, M.; Ritchie, E.; Watermeyer, K.; Bryan, B. Improving the assessment of food system sustainability. Lancet Planet. Health 2019, 3, e62-e63. [CrossRef]

5. Clarke-Sather, A.; Tang, X.; Yonglan, X.; Qu, J. The Impact of Green Water Management Strategies on Household-Level Agricultural Water Productivity in a Semi-Arid Region: A Survey-based Assessment. Water 2017, 10, 11. [CrossRef]

6. Wang, Q.; Ma, Z.; Ma, Q.; Liu, M.; Yuan, X.; Mu, R.; Zuo, J.; Zhang, J.; Wang, S. Comprehensive evaluation and optimization of agricultural system: An emergy approach. Ecol. Indic. 2019, 107, 105650-105651. [CrossRef]

7. Norse, D.; Ju, X. Environmental costs of China's food security. Agric. Ecosyst. Environ. 2015, 209, 5-14. [CrossRef]

8. Lewis, C. Feeding the World: Brazil's Transformation into a Modern Agricultural Economy, by Herbert S. Klein and Francisco Vidal Luna. Engl. Hist. Rev. 2020, ceaa295. [CrossRef]

9. Safieddin Ardebili, S. Green electricity generation potential from biogas produced by anaerobic digestion of farm animal waste and agriculture residues in Iran. Renew. Energy 2020, 154, 29-37. [CrossRef]

10. Wang, X.; Rungsuriyawiboon, S. Agricultural efficiency, technical change and productivity in China. Post-Communist Econ. 2010, 22, 207-227. [CrossRef]

11. Rungsuriyawiboon, S.; Zhang, Y. Examining the economic performance of Chinese farms: A dynamic efficiency and adjustment cost approach. Econ. Anal. Policy 2017, 57, 74-87. [CrossRef]

12. Luminita, C.; Jean, A.; Zahariav, M.; Gogonea, R.-M. A regional agricultural efficiency convergence assessment in RomaniaAppraising differences and understanding potentials. Land Use Policy 2020, 99, 104838. [CrossRef]

13. Sabasi, D.; Shumway, C.R. Climate change, health care access and regional influence on components of U.S. agricultural productivity. Appl. Econ. 2018, 50, 6149-6164. [CrossRef]

14. Ghoshal, P.; Goswami, B. Measurement of Production Efficiency: A Case of Indian Agricultural Production in Post Reforms Period. Asian J. Agric. Ext. Econ. Sociol. 2016, 13, 1-10. [CrossRef]

15. Shuaibu, M.; Nchake, M. Credit Market Conditions and Agricultural Performance in Sub-Saharan Africa. J. Dev. Areas 2020, 54, 41-53. [CrossRef]

16. Shanmugam, K.; Venkataramani, A. Technical efficiency in agricultural production and its determinants: An exploratory study at the district level. Indian J. Agric. Econ. 2006, 61, 169-184.

17. Sunge, R.; Ngepah, N. Agricultural trade liberalization, regional trade agreements and agricultural technical efficiency in Africa. Outlook Agric. 2019, 49, 003072701987055. [CrossRef]

18. Quiroga, S.; Suárez, C.; Fernández-Haddad, Z.; Philippidis, G. Levelling the playing field for European Union agriculture: Does the Common Agricultural Policy impact homogeneously on farm productivity and efficiency? Land Use Policy 2017, 68, 179-188. [CrossRef]

19. Bahta, Y.; Jordaan, H.; Sabastain, G. Agricultural Management Practices and Factors Affecting Technical Efficiency in Zimbabwe Maize Farming. Agriculture 2020, 10, 78. [CrossRef]

20. Ma, W.; Renwick, A.; Yuan, P.; Ratna, N. Agricultural cooperative membership and technical efficiency of apple farmers in China: An analysis accounting for selectivity bias. Food Policy 2018, 81, 122-132. [CrossRef]

21. Iqbal, N.; Sial, M. Semi-parametric analysis of agricultural production under dichotomy of inputs. Agric. Econ. (Zemědělská Ekon) 2016, 64, 378-388. [CrossRef]

22. Ea, O. An Empirical Analysis of the effect of Agricultural Input on Agricultural Productivity in Nigeria. Int. J. Agric. Sci. Food Technol. 2017, 77-85. [CrossRef]

23. Chen, Z.; Huffman, W.E.; Rozelle, S. Farm technology and technical efficiency: Evidence from four regions in China. China Econ. Rev. 2009, 20, 153-161. [CrossRef]

24. Anselin, L. Thirty Years of Spatial Econometrics. Pap. Reg. Sci. 2010, 89, 3-25. [CrossRef]

25. Chica-Olmo, J.; González Morales, J.; Zafra, J. Effects of location on Airbnb apartment pricing in Málaga. Tour. Manag. 2020, 77, 103981. [CrossRef]

26. Chen, N.; Jin, X. Industry risk transmission channels and the spillover effects of specific determinants in China's stock market: A spatial econometrics approach. N. Am. J. Econ. Financ. 2020, 52, 101-137. [CrossRef]

27. Copiello, S.; Grillenzoni, C. Solar Photovoltaic Energy and Its Spatial Dependence. Energy Procedia 2017, 141, 86-90. [CrossRef] 
28. Najkar, N.; Kohansal, M.; Ghorbani, M. Impact of Industrial Agglomeration on Productivity: Evidence from Iran's Food Industry. Chin. Geogr. Sci. 2019, 30, 309-323. [CrossRef]

29. Cardamone, P. Productivity and spatial proximity: Evidence from the Italian food industry. J. Int. Rev. Appl. Econ. 2020, 34, 327-341. [CrossRef]

30. Accetturo, A.; Giacinto, V.D.; Micucci, G.; Pagnini, M. Geography, productivity, and trade: Does selection explain why some locations are more productive than others? J. Reg. Sci. 2018, 58, 949-979. [CrossRef]

31. Wu, J.; Ge, Z.; Han, S.; Xing, L.; Zhu, M.; Zhang, J.; Liu, J. Impacts of agricultural industrial agglomeration on China's agricultural energy efficiency: A spatial econometrics analysis. J. Clean. Prod. 2020, 260, 121011. [CrossRef]

32. Lele, U.; Goswami, S. Agricultural policy reforms: Roles of markets and states in China and India. Glob. Food Secur. 2020, 26, 100371. [CrossRef] [PubMed]

33. Apata, T. Public spending mechanisms and gross domestic product (GDP) growth in the agricultural sector (1970-2016): Lessons for Nigeria from agricultural policy progressions in China. Bull. Geogr. Socio-Econ. Ser. 2019, 44, 57-72. [CrossRef]

34. Arnade, C.; Cooke, B.; Gale, F. Agricultural Price Transmission: China Relationships with World Commodity Markets. J. Commod. Mark. 2017, 7, 28-40. [CrossRef]

35. Leontief, W. Input-Output Data Base for Analysis of Technological Change. Econ. Syst. Res. 1989, 1, 287-295. [CrossRef]

36. Charnes, A.; Cooper, W.W.; Rhodes, E. Measuring the efficiency of decision making units. Eur. J. Oper. Res. 1978, 2, 429-444. [CrossRef]

37. Moutinho, V.; Madaleno, M.; Macedo, P. The effect of urban air pollutants in Germany: Eco-efficiency analysis through fractional regression models applied after DEA and SFA efficiency predictions. Sustain. Cities Soc. 2020, 59, 102204. [CrossRef]

38. Namazi, M.; Mohammadi, E. Natural resource dependence and economic growth: A TOPSIS/DEA analysis of innovation efficiency. Resour. Policy 2018, 59, 544-552. [CrossRef]

39. Laurinavičius, E.; Rimkuvienè, D. The Comparative Efficiency Analysis of EU Members Agriculture Sectors. Rural Sustain. Res. 2017, 37, 10-19. [CrossRef]

40. Battese, G.E.; Coelli, T.J. Frontier production functions, technical efficiency and panel data: With application to paddy farmers in India. J. Product. Anal. 1992, 3, 153-169. [CrossRef]

41. Greene, W.H. The econometric approach to efficiency analysis. Meas. Product. Effic. Product. Growth 2008, 1, 92-250.

42. Bokusheva, R. Measuring dependence in joint distributions of yield and weather variables. Agric. Financ. Rev. 2011, 71, 429-444. [CrossRef]

43. Xin, X.; Zhang, Y.; Wang, J.; Nuetah, J.A. Effects of Farm Size on Technical Efficiency in China's Broiler Sector: A Stochastic Meta-Frontier Approach. Can. J. Agric. Econ./Rev. Can. D'agroeconomie 2016, 64, 493-516. [CrossRef]

44. Huang, W.; Xu, L.; Guo, Y. Analysis on Technical Efficiency and Influencing Factors of Agricultural Production in China-Based on the Stochastic Frontier Analysis model. E3s Web Conf. 2021, 235. [CrossRef]

45. Ali, I.; Xue-xi, H.; Khan, I.; Ali, H.; Baz, K.; Khan, S.U. Technical efficiency of hybrid maize growers: A stochastic frontier model approach. J. Integr. Agric. 2019, 18, 2408-2421. [CrossRef]

46. Mango, N.; Makate, C.; Hanyani-Mlambo, B.; Siziba, S.; Lundy, M. A stochastic frontier analysis of technical efficiency in smallholder maize production in Zimbabwe: The post-fast-track land reform outlook. Cogent Econ. Financ. 2015, 3, 1117189. [CrossRef]

47. Akhtaruzzaman, K.M.; Ratna, B.; Rasmus, N.; Ayoe, H. Production risk, technical efficiency, and input use nexus: Lessons from Bangladesh aquaculture. J. World Aquac. Soc. 2021, 52, 57-72.

48. Otsuka, A.; Goto, M.; Sueyoshi, T. Energy efficiency and agglomeration economies: The case of Japanese manufacturing industries. Reg. Sci. Policy Pract. 2014, 6, 195-212. [CrossRef]

49. Lee, L.-f. Consistency and Efficiency of Least Squares Estimation for Mixed Regressive, Spatial Autoregressive Models. Econom. Theory 2002, 18, 252-277. [CrossRef]

50. Elhorst, J.P. Spatial Panel Data Analysis. In Encyclopedia of GIS; Springer: Cham, Switzerland, 2015.

51. LeSage, J.; Pace, R.K. Introduction to Spatial Econometrics; CRC Press: Boca Raton, FL, USA, 2009.

52. Moran, P.A.P. Notes on Continuous Stochastic Phenomena. Biometrika 1950, 37, 17-23. [CrossRef] [PubMed]

53. Anselin, L. Spatial Econometrics: Methods and Models; Springer: Amsterdam, The Netherlands, 1988.

54. Evenson, R.E. Spillover Benefits of Agricultural Research: Evidence from U.S. Experience. Am. J. Agric. Econ. 1989, 71, 447-452. [CrossRef]

55. Zheng, Q.; Lin, B. Impact of industrial agglomeration on energy efficiency in China's paper industry. J. Clean. Prod. 2018, 184, 1072-1080. [CrossRef]

56. Chang, C.-L.; Oxley, L. Industrial agglomeration, geographic innovation and total factor productivity: The case of Taiwan. Math. Comput. Simul. 2009, 79, 2787-2796. [CrossRef]

57. Futagami, K.; Ohkusa, Y. The Quality Ladder and Product Variety: Larger Economies May Not Grow Faster. Jpn. Econ. Rev. 2003, 54, 336-351. [CrossRef]

58. Rice, P.; Venables, A.J.; Patacchini, E. Spatial determinants of productivity: Analysis for the regions of Great Britain. Reg. Sci. Urban Econ. 2006, 36, 727-752. [CrossRef]

59. Robert-Nicoud, F.; Sbergami, F. Home-market vs. vote-market effect: Location equilibrium in a probabilistic voting model. Eur. Econ. Rev. 2004, 48, 155-179. [CrossRef] 